\title{
Melatonin on hypothyroidism and gonadal development in rats: review
}

\author{
Yuri Mateus Lima de Albuquerque ${ }^{1}$, Welma Emídio da Silva ${ }^{1}$, Francisco de Assis Leite Souza ${ }^{1}$, Valéria Wanderley \\ Teixeira $^{1}$, Álvaro Aguiar Coelho Teixeira ${ }^{1}$
}

\author{
${ }^{1}$ Departamento de Morfologia e Fisiologia Animal, Universidade Federal Rural de Pernambuco- PE, Brazil
}

\begin{abstract}
We evaluated the evidence in research on the effects of melatonin on hypothyroidism and gonadal development. According to the World Health Organization, thyroid disorders due to iodine deficiency affect about 740 million people worldwide. Hypothyroidism is a thyroid dysfunction characterized by hypometabolism of the gland, with reduced or physiologically normal T3 and T4 serum levels, and high TSH level. This disorder occurs mainly in adult women in the reproductive phase, with a prevalence of $2 \%$ among the world's female population, with profound repercussions on gestation and fetal formation. During the gestational period, the thyroid is initially stimulated by high concentrations of human chorionic gonadotrophin; thus, maintaining maternal euthyroidism during pregnancy and lactation is fundamental for fetal growth and development. Besides, the hormones produced by this gland are involved in the formation of various organs, such as the skin, brain and gonads. Hypothyroidism is associated with several menstrual abnormalities, anovulation and hyperprolactinemia, resulting in a high rate of abortions, premature births, placental rupture, and weight-related neonatal deficits. In addition, there are studies showing that hypothyroidism can affect ovarian morphology (number of ovarian follicles) and testicular morphology (changes in the testicular-lumen epithelium). Melatonin is a hormone known to modulate the estrous cycle and pregnancy, and studies show that the exogenous application of melatonin increased T4 levels in female rats and controlled the decrease in T3 serum levels, reverting the sigs of hypothyroidism.
\end{abstract}

Keywords: melatonin, gonads, hypothyroidism

\section{INTRODUCTION}

The World Health Organization (WHO) stated that approximately 740 million people worldwide suffer from thyroid disorders due to iodine deficiency (Abalovich et al., 2002). Hypothyroidism is a pathological condition of thyroid hormone deficiency that can lead to serious adverse health effects. Hypothyroidism is divided into two different biochemical types: overt, where the thyroid-stimulating hormone (TSH) concentrations are above the reference range and free thyroxine concentrations below regular range or subclinical, where although the TSH concentrations are above the reference range, free thyroxine concentrations are within the normal range (Chaker et al., 2017). This disorder is present in $2 \%$ of the world's female population (Hapon et al., 2010), interfering directly in gestation and fetal formation (Maciel \& Magalhães, 2008).

A hormone that plays a regulatory role in the pregnancy and thyroid physiology is melatonin. This hormone modulates the estrous cycle and pregnancy (Maganhin et al.,
2013) and reverses signs of hypothyroidism in hypothyroid rats with the administration of exogenous melatonin (Bondarenko et al., 2011).

This review summarizes the connection between melatonin with hypothyroidism and gonadal embryogenesis.

\section{LITERATURE REVIEW}

\section{Thyroid}

The thyroid gland weighs 20 grams on average in the human species, and 40 milligrams in rats. It comprises two lobes and an isthmus that unites them. In addition, the pyramidal lobe, which may originate from one of the lobes or from the isthmus itself, is present in 12-65\% (Soukup et al., 2001; Ayadi et al., 2017; Kaklamanos et al., 2017). While each lobe is $4-5 \mathrm{~cm}$ high, $2-3 \mathrm{~cm}$ wide and $2-4 \mathrm{~cm}$ thick, the lobes are usually located between the first and fourth tracheal rings. Left and right lobes partially surround the front trachea. Laterally, there is the carotid sheath and the sternocleidomastoid muscle (Menzilcioglu et al., 2016).

The thyroid gland in humans develops from the neural crest and the primitive pharynx, assuming its position still attached to the thyroglossal duct. The thyroid is one of the first endocrine glands to become active in humans, being composed of thyroid follicles, formed by cubic epithelial cells, the thyrocytes (Menzilcioglu et al., 2016). Thyrocytes have polarity: the basal zone is related to the interstitial connective tissue, where the vessels and nerves pass, while the apical pole points to the light of the follicle. The apical zone has pseudopods that play a fundamental role in capturing the elements of the colloid, hormonal synthesis and its release (Chastain \& Ganjan, 1986).

The thyroid by through the TSH stimulation (thyroid stimulating hormone) synthesizes thyroxine (T4) and triiodothyronine (T3) hormone, regulating the body's metabolism, of fundamental importance in embryogenesis (Menzilcioglu et al., 2016). However, unlike humans, in which thyroid hormones are secreted even in the first trimester of gestation (Smallridge \& Lendenson, 2001), in rats the development of the thyroid is slower, becoming active and producing the thyroid hormones around the $17^{\text {th }}$ day of gestation (Choksi et al., 2003), making the rodents' fetuses' embryogenesis dependent on maternal thyroid hormones.

After birth, the thyroid and the hypothalamic-pituitary-thyroid axis in rats are immature compared to humans. During the first 21 postnatal days, this gland grows due to increased colloid deposition and follicular cell proliferation, which remains constant from birth until the $21^{\text {st }}$ day of life, reducing after that period (Parker \& Picut, 2016). Histologically, throughout the postnatal period in rats, the thyroid follicles tend to be wider at the periphery of the gland, representing a progression in follicle maturation from the center to the periphery. Rats' thyroids fully develop on the $21^{\text {st }}$ postnatal day, but becomes 
endocrinologically complete only on the $28^{\text {th }}$ postnatal day (Parker \& Picut, 2016). In addition to follicular cells, the thyroid gland contains the $\mathrm{C}$ cells, which produce calcitonin. These cells become visible in a light microscope around the $21^{\text {st }}$ postnatal day, having a low mitotic activity until the $42^{\text {nd }}$ postnatal day. It is reported that from birth to the $120^{\text {th }}$ postnatal day in rats, the number of $C$ cells increases nine fold, and their size increased by up to four times (Parker \& Picut, 2016).

Its sexual dimorphism in rats becomes apparent around the $40^{\text {th }}$ postnatal day, in which the male gland has less colloid than in females, and its cells have cytoplasmic vacuoles (Parker \& Picut, 2016). This dimorphism is due to the male follicular epithelium synthesizing the androgen hormone through the TSH feedback, where the levels of this hormone are lower in male rats until the $21^{\text {st }}$ postnatal day (Banu et al., 2002).

\section{Hypothyroidism}

Hypothyroidism is a common thyroid dysfunction, characterized by hypometabolism of the gland, and it can be identified as overt hypothyroidism when T3 and T4 serum levels are reduced, and the TSH level is elevated (Welsh \& Soldin, 2016; Feldt-Rasmussen \& Klose, 2016); or as subclinical hypothyroidism, when serum levels of T3 and T4 are physiologically normal, and TSH levels are elevated (Shizuma, 2016).

Thyroid disorders represent a major public healthcare problem worldwide, following diabetes as the most common endocrine disorder in adult medical practice, and presenting a myriad of devastating consequences if not treated in advance (Vanderpump, 2011). The epidemiology and clinical features of thyroid disease are determined by the supply of iodine, an essential element in the synthesis of thyroid hormones. In addition, excessive variations in iodine levels may represent adverse health effects (Brotfain et al., 2013), such as increased or decreased metabolic rate and thermogenesis; and it is also correlated with an increase in body mass index (BMI) and obesity (Yim, 2016).

The relationship between TSH and free T4 is so sensitive that a small decrease in free T4 may result in an increase in serum TSH, raising its level above the reference range, while the free T4 level is still within the standard levels (Surks et al., 2004). Subclinical hypothyroidism is a disorder that occurs most frequently in women, the elderly and in areas where there is a greater intake of iodine. The prevalence rate varies from four to $10 \%$ in the adult population, and if there is an increased intake of iodine, it goes up to $24 \%$ (Biondi \& Cooper, 2008; Vanderpump, 2011). In $80 \%$ of patients with subclinical hypothyroidism, there are a greater number of anti-thyroid antibodies, which means that in most cases an autoimmune process is present, causing such a condition (Fatourechi, 2009).

The clinical course of subclinical hypothyroidism may progress towards the development of overt hypothyroidism, as well as toward the normalization of TSH values. A study carried out with 82 women with increased TSH levels showed that after a 10 -year period, $28 \%$ of them developed overt hypothyroidism; $68 \%$ of them still had subclinical disorder, while $4 \%$ of them had normal TSH (Huber et al., 2002).

Díez \& Iglesias (2004) examined the natural course of subclinical hypothyroidism in 107 patients, and showed that patients with the mild disorder (TSH levels of 5.0 to $9.9 \mathrm{mU} / \mathrm{I}$ ) are more likely to have normalized TSH values compared to patients whose TSH is greater than 10.0 $\mathrm{mU} / \mathrm{l}$. There are also reports that the TSH value was the most important prognostic factor for the diagnosis of subclinical hypothyroidism (Díez \& Iglesias, 2004).

\section{Hypothyroidism and pregnancy}

Since ovarian and placental development depend on the complex interaction between endocrine, paracrine and autocrine factors, thyroid dysfunctions compromise fetal fertility, gestation and development in humans and rodents (Choksi et al., 2003; Hapon et al., 2010).

Thyroxine (T4) and triiodothyronine (T3) act on ovarian and placental tissue, modulating their metabolism and development (Galton et al., 2001; James et al., 2007). Specific receptors for T3 are present in the nucleus of ovarian cells, so that this hormone can have a direct effect on these tissues (Evans et al., 1983; Maruo et al., 1992). However, the placenta, in addition to expressing receptors for thyroid hormones (Leonard et al., 2001), accumulates and metabolizes T3 and maternal T4 (Calvo et al., 1992). Thus, thyroid dysfunctions are associated with several ovarian and placental morpho-functional changes with impaired reproductive efficiency (Choksi et al., 2003).

Hypothyroidism is common in adult and reproductive women, with a prevalence of $2 \%$ in the worldwide female population (Hapon et al., 2010). The incidence of hypothyroidism during pregnancy is between $0.3 \%$ and $2.5 \%$ (Idris et al., 2005), having profound repercussions on gestation and fetal formation (Maciel \& Magalhães, 2008). During gestation, the thyroid is initially stimulated by high concentrations of human chorionic gonadotrophin (hCG); thus, maintaining maternal euthyroidism during gestation and lactation, which is critical for fetal growth and development (Maciel \& Magalhães, 2008), since the hormones produced by this gland are involved in the formation of organs such as the skin (Amerion et al., 2013), brain (Morreale de Escobar et al., 2004) e testis (Wagner et al., 2008) of the fetuses. Hypothyroidism is associated with several menstrual abnormalities, anovulation and hyperprolactinemia (Sanyal \& Raychaudhury, 2016), resulting in a high rate of miscarriages, premature births, placental rupture, and weight-related neonatal deficiencies (Amerion et al., 2013).

Adaptive changes in the maternal thyroid occur during gestation, in response to the need to provide the fetus with T3 and T4 until the fetal hypothalamic-pituitary-thyroid system is functional. For this, the maternal thyroid increases in volume, as well as its uptake of iodide (Versloot et al., 1997). In addition, estrogen levels stimulate the expression of TBG (thyroxine binding globulin) in the liver and almost double their serum concentration. The serum increase of TBG occurs concomitantly with the increase of total serum concentrations of T3 and T4 (Karabinas \& Tolis, 1998).

The main function of T3 is to regulate cell carbohydrates and proteins metabolism. Thus, changes in T3 plasma levels can affect all organs and organ systems, with important effects on the cardiovascular, nervous, immune and genital systems (Choksi et al., 2003). T3 levels in laboratory rodents influence the control of the estrous cycle, behavior, maintenance of pregnancy, fetal growth and lactation (Vasudevan et al., 2002). The deiodinases, proteins responsible for the activation of thyroid hormones present in human and rodent placentas rapidly metabolize maternal T4 to T3, which will be used by the fetus, with a significant amount of T4 also being transferred (Chan \& Kilby, 2000). The placenta is freely permeable to iodine and thyrotropin releasing hormone (TRH), but not to TSH. We believe that maternal TRH transferred to the fetus may play an important role in the control of fetal thyroid function before complete maturation of the hypothalamic-pituitary-thyroid axis.

The authors reported that rat gestations induced to hypothyroidism is prolonged, lasting about 24 days, and generating on average nine pups per gestation, number 
smaller than that of the control group average, which are usually of 12 pups. In addition, rats with low levels of thyroid hormones exhibit higher levels of progesterone at the end of gestation, as well as lower levels of estrogen and litters with lower weights when compared to data from control groups (Hapon et al., 2003). Another observed effect relating this dysfunction to gestation is the prolongation of corpus luteum function in pregnant rats (Hapon et al., 2007), where there is a reduction in the proliferation, apoptosis and expression of angiogenic factors in the corpus luteum of pregnant rats (Silva et al., 2014).

Induced hypothyroidism compromises the placental layers of the rat, and it increases glycogen cell population in the spongiotrophoblast layer relative to the cytotrophoblastic cells, and interfere with the vascular development of the placental labyrinth, thus reducing proliferative activity and cellularity, and increasing the apoptotic rate of the three layers of the placental disc (Silva et al., 2012). This morphological alteration caused by such dysfunction may also cause low body weight of the litters of rats induced to hypothyroidism, this is because there is a reduction in the area occupied by fetal capillary in the placental labyrinth at 14 days of gestation, and may be insufficient to establish with maternal blood, causing low fetal weight (Silva et al., 2012).

Thus, a state of clinical or subclinical hypothyroidism may be worsened by the pregnancy state, and adequate function of the mammary glands may be impaired. The impact on mother and offspring is well documented, and one of its most pronounced consequences is delayed growth and delayed maturation of the newborn, causing mental retardation and subnormal height. Although most of these effects are attributed to the hypothyroid state of infants, any change in maternal metabolism that could lead to decreased milk production or excretion could further complicate offspring development (Hapon et al., 2003).

\section{Gonadal embryology}

Gonad development has two phases. The initial phase has the appearance of the so-called indifferent, bipotential gonad or genital crest, which is identical in males and females. The cell lines that compose it are bipotential, being able to turn into male or female gonads. The second stage is testicle or ovary development (Wilhelm et al., 2007). The gonads develop from the intermediate mesoderm, which is situated in the longitudinal urogenital crests; the most medial part of these crests are the gonadal ridges, occurring during the fifth week of gestation in humans, and around the $10^{\text {th }}$ day of gestation in rats (Zayed et al., 2007). During development, the primordial germ cells migrate from the yolk sac wall through the dorsal mesentery of the large intestine to occupy the gonadal ridges. The arrival of these cells induces the cells in the crests to form primitive sex chords (derived from mesonephros and overlapping celomic epithelium). At this stage, the gonad is indifferent to sex, and consists of an external cortex and an inner medulla. If the germ cells do not migrate to the gonadal ridges, the gonads do not grow (Mitchell \& Sharma, 2009).

In embryos with no testicle-determining factors, the primitive sexual cords extend into the gonad medulla, degenerate and form a vascular stroma, resulting in an ovary (Mitchell \& Sharma, 2009). Regarding ovarian development, in the postnatal day (PND) 3, primordial, primary and secondary follicles are apparent, with a thick peripheral cortex of primordial follicles and a central nucleus of primary and secondary follicles. At no other time in the development of the ovary is the primordial follicle the most prominent feature. In PND 10, the secondary and early antral follicles are immature compared to the follicles of the adult animal in the active estrous cycle. Around PND 21 , large antral follicles can be seen occasionally within the medulla. These large antral follicles in the medulla of the infant ovary can be distinguished from the ovulatory follicles of the peripuberal and mature ovary, since the ovulatory follicles that eventually ovulate are more commonly located in the external ovarian cortex. In PND 30, the most apparent morphological characteristic is the appearance of the ovulatory follicle in the external cortex. These follicles are of sufficient size for ovulation and have a distended antrum and a primary oocyte coated by the cumulus oophorus layer (Picut et al., 2014; 2015a).

In embryos with testes determining factors, the primitive sexual cords proliferate and penetrate the medulla forming the testicular cords. Some of these cells differentiate into Sertoli cells, while the remaining form the seminiferous tubules. The testicular cords anastomose to form the rete testis, which becomes continuous with 15 to 20 persistent mesonephric tubules, the efferent duct. The testes determining factor also induces the differentiation of mesenchymal gonadal cells into interstitial Leydig cells (Mitchell \& Sharma, 2009). We believe that Sertoli cells act as the organizing center of the male gonad, and orchestrate the differentiation of all other cell types (Wilhelm et al., 2007).

In PND 3, the testes consist of gonocyte-coated tubules and mitotically active Sertoli cells. In PND 15, spermatogonia are still mitotically active and spermatogonia reach the maximum density forming a thick pseudo-stratified layer with Sertoli cells. The mitotic rate in the population of spermatogonial cells decreases compared to that of the early childhood period (PND 3), and apoptotic spermatogonia are present in the center of the tubules. The period between the PNDs 21 to 30 holds the maintenance of the first wave of spermatogenesis in rounded spermatids, and mainly by a significant increase in the tubular diameter (Picut et al., 2015b).

\section{Melatonin}

The pineal gland produces and secretes melatonin and other peptides still poorly defined, through the release of noradrenaline (NE) by intraparenchymal nerve fibers, where this release and activity of the pineal gland are activated in dark environment and inhibited by light (Maganhin et al., 2009; Junqueira \& Carneiro, 2013). Also known as $\mathrm{N}$-acetyl-5-methoxytryptamine, melatonin derives from the serotonin that has tryptophan as the precursor, and is the main product of the pineal, exhibiting high solubility and a light yellow stain. It is transported through the plasma connected to proteins such as albumin (Sumaya et al., 2005; Maganhin et al., 2008).

With specific receptors in cell membranes (MT1 and MT2), melatonin has several functions as modulating the circadian cycle of antioxidant enzymes, bone metabolism, growth of ovarian follicles, ovulation, luteinizing hormone, fertilization and implantation (Tamura et al., 2009; 2014; Sharma et al., 2015). This hormone can also exert antioxidant functions, due to its small molecular size and its lipolipid properties, being able to cross all cell membranes and reach intracellular compartments, as well as the nucleus and mitochondria, organelles with high concentrations (León et al., 2005; Waseem et al., 2017), preventing damage to DNA (Sousa Coelho et al., 2018). The reduction in the occurrence and growth of tumors causes melatonin to be the most important natural oncostatic hormone in the human body (Reiter, 2004; Cabrera et al., 2010). We also believe that melatonin plays an important role during the life cycle, acting in growth, development, maturation and aging, decreasing its plasma concentration with the individual's age (Tamura et al., 2009; 2014). 
Melatonin is cited in several studies as an important part of the neuroendocrine system, influencing the control of circadian rhythms and controlling various physiological processes (Ferreira et al., 2010). The sites in which the interaction between melatonin and the endocrine system occur are still unclear. We believe that the activity of this hormone involves the hypothalamus, the pituitary, the gonads, and the pineal gland, the main one responsible for its production (Reiter, 1995).

\section{Melatonin and the gonads}

Melatonin is a broad-spectrum functional hormone responsible for regulating internal hormonal changes in response to variations according to periods of light and darkness (Mukherjee \& Haldar, 2014). In photoperiodic species, melatonin secretion by the pineal gland is responsible for the effects of day length on the seasonal reproduction cycle (Maldonado et al., 2012). In these species, melatonin has a pro-gonadotrophic effect, increasing follicle-stimulating hormone (FSH) and luteinizing hormone (LH) peak concentrations, probably by blocking the inhibitory effects of sex steroids on ovulation (Rocha et al., 2011).

In species with non-seasonal reproduction, that is, non-photoperiodic, pre-ovulatory release of gonadotrophins is controlled by a circadian cycle. These species present a daily circadian rhythm of melatonin release (Claustrat et al., 2005). There are melatonin receptors, MT1 and MT2, in both male and female gonads of these species (Maganhin et al., 2008; Mukherjee \& Haldar, 2014), thus reaffirming its antigonadotrophic properties, such as inhibition of gonadal development, spermatogenesis and androgen production in males and absence of follicles, corpus luteum and proliferation of interstitial tissue in females (Soares Jr et al., 2003).

Melatonin plays a significant role in fetal programming, since the follicular fluid has high concentrations of it, suggesting its direct participation in oocyte maturation and embryo development, due to its ability to reduce oxidative stress in the ovarian follicles and to protect these oocytes of free radical damage (Nelissen et al., 2011; Brzezinski et al., 1987). Melatonin levels in maternal plasma may increase during pregnancy, however, in compromised pregnancies, this hormone in the mother and fetus may be affected (Chen et al., 2013).

As for female gonads, the mechanisms that control folliculogenesis are still unclear; however, hormones and several growth factors are involved (Escames et al., 2012). Studies have demonstrated the presence of melatonin receptors (MT1 and MT2) in the ovarian follicles, thus supporting the hypothesis of its performance in ovarian physiology (Soares Jr et al., 2003; Lee et al., 2014). Regarding the male gonads, melatonin plays a protective role in testicular development both in vitro and in vivo, as well as regulates it by controlling the secretion of neurohormones (particularly GnRH) and testosterone (Li \& Zhou, 2015).

According to Gholami et al. (2013), melatonin may improve the structure of testicular tissue. Such researchers have observed that this hormone can induce cell proliferation in normal cells and induce apoptosis in damaged cells (Gholami et al., 2014) (Niu et al. 2016); however, its addition to the spermatogenic stem cell (SSCs) culture medium could increase SSC proliferation by stimulating glial-derived neutrophilic factor (GDNF) production in the Sertoli cells. Furthermore, low levels of melatonin during pregnancy and lactation matrix results in an involution of the testes offspring, indicating that their levels during pre and postnatal development interfere with testicular growth (Tuthill et al., 2005). We also know that pinealectomy increases testicular weight, while administration of exogenous melatonin decreases the above-mentioned weight in non-pinealectomized rats (Kuş et al., 2000; Akosman et al., 2013).

\section{Melatonin and thyroid}

There is a significant relationship between the thyroid and pineal glands, suggesting that deficiencies in thyroid function may alter the release of melatonin (Rom-Bugoslavskaia \& Bondarenko, 1984). Hypothyroidism causes a significant decrease in plasma melatonin levels, when we compare rodents induced to it to healthy rodents. Rats induced to hyperthyroidism have higher levels of this indolamine in plasma, suggesting a relationship between the thyroid disorders and the pineal gland (Belviranli \& Baltaci, 2008; Baltaci \& Mogulkoc, 2017; 2018). Likewise, Bondarenko et al. (2011) demonstrated that signs of hypothyroidism in rats with low levels of melatonin due to exposure to constant light were reversed with their exogenous application.

Laskar et al. (2015) investigated the presence of receptors of this hormone in the thyroid gland, and reported that exogenous application of melatonin increased T4 levels in female rats. Their results were also found by Skipor et al. (2010) that, through the exogenous application of this indolamine, found a prevention in the decay of serum T3 levels and a control in the decay of T4 levels.

Effects of hypothyroidism on morphometry and cell proliferation

There are several studies showing that thyroid hormones affect spermatogenesis by promoting changes in basal metabolic activity and cellular respiration of the testes (Oppenheimer et al., 1987; Mutvei \& Nelson, 1989; Fadlalla et al., 2017), or by affecting Leydig cells, resulting in the reduction of testosterone secretion (Zirkin et al., 1980; Mendis-Handagama et al., 1991). In addition, in hypothyroid rats, testicular morphology is also affected, where there is a modification in the relation of the testicular-lumen epithelium, causing changes in lumen size ( $\mathrm{A} i$ et al., 2007).

Previous studies have shown that such a thyroid disorder can also affect ovarian morphology by altering the number of ovarian follicles (Meng et al., 2017). The transition from the primary to the secondary follicle (pre-antral stage) is controlled by intra-ovarian factors such as GDF-9 (Differentiation Factor and Growth-9) (McGrath et al., 1995; Orisaka et al., 2006). We know that the thyroid influences this mitogenic factor, although the mechanism is still not fully understood (Dong et al., 1996; Hayashi et al., 1999).

Along with morphological changes, we know that during pregnancy, in humans and rodents, the uterus undergoes a series of morphofunctional changes in order to accommodate the growing embryo, but the hypothyroid state decreases the proliferative rate of epithelial cells, stroma and myometrium by reducing the response of uterine cells to estrogen (Kirkland et al., 1981). In addition to this organ, hypothyroidism may also cause a decrease in the expression of proliferative antigens in placentas and testes of rats (Silva et al., 2012; Fadlalla et al., 2017), thus showing the anti-proliferative effect of hypothyroidism.

\section{CONCLUSION}

This selective literature review supports the proposition that maternal hypothyroidism affects the development of the embryo, focusing specially on their gonads. As it is apparent from the studies hereby mentioned, melatonin may play a role in the protection of the effects of hypothyroidism in both mothers and their offspring, by preventing the decrease in thyroid hormone levels in rats, and reversing signs of hypothyroidism in rats. Additionally, 
melatonin seems to interfere directly in the embryogenesis of both gonads, since there are receptors for this hormone in ovaries and testicles. In addition, it is still unclear how melatonin affects the ovaries. We know that in testicles, melatonin plays a protective role by stimulating normal cell proliferation, but it induces apoptosis on damaged cells. We hope that because of this paper the interest in the effects of hypothyroidism in the embryology of fetuses from hypothyroid mothers will increase, giving relevance to a disease that affects a growing number of females in reproductive ages, since studies on this topic are scarce.

\section{CONFLICT OF INTERESTS}

The authors declare that there are no conflicts of interest.

\section{Corresponding author:}

Yuri Mateus Lima de Albuquerque

Departamento de Morfologia e Fisiologia Animal

Universidade Federal Rural de Pernambuco

PE, Brazil.

E-mail: yuri.lima-de-albuquerque@insa-lyon.fr

\section{REFERENCES}

Abalovich M, Gutierrez S, Alcaraz G, Maccallini G, Garcia $A$, Levalle $O$. Overt and Subclinical Hypothyroidism Complicating Pregnancy. Thyroid. 2002;12:63-8. PMID: 11838732 DOI: $10.1089 / 105072502753451986$

Ai J, Zarifkar A, Takhshid MA, Alavi J, Moradzadeh M. The effect on thyroid activity on adult rat spermatogenesis. Iran J Vet Med. 2007;8:155-60. PMID: 7428694 DOI: 10.22099/IJVR.2007.2687

Akosman MS, Özdemir V, Taskiran N, Akalan MA, Bülbül A. Effect of Photoperiod and Melatonin on Volume and Cellular Parameters of Testis in Pinealectomized Rats. Int J Morph. 2013;31:1062-7. DOI: 10.4067/S071795022013000300046

Amerion M, Tahajjodi S, Hushmand Z, Mahdavi-Shahri $N$, Nikravesh MR, Jalali M. The effect of maternal thyroid disorders (hypothyroidism and hyperthyroidism) during pregnancy and lactation on skin development in wistar rat newborns. Iran J Basic Med Sci. 2013;16:665-74. PMID: 23826487

Ayadi M, Gasbi A, Meddeb K, Mokrani A, Yahiaoui $Y$, Letaief $F$, Charaiet $N$, Rais $H$, Mezlini A. Primary leiomyosarcoma of thyroid gland: the youngest case. Pan Afr Med J. 2017;26:113. PMID: 28533836 DOI: 10.11604/ pamj.2017.26.113.11472

Baltaci AK, Mogulkoc R. Leptin, NPY, Melatonin and Zinc Levels in Experimental Hypothyroidism and Hyperthyroidism: The Relation to Zinc. Biochem Genet. 2017;55:223-33. PMID: 28097455 DOI: 10.1007/s10528017-9791-z

Baltaci AK, Mogulkoc R. Leptin, neuropeptide Y (NPY), melatonin and zinc levels in experimental hypothyroidism and hyperthyroidism: relation with melatonin and the pineal gland. Horm Mol Biol Clin Investig. 2018;34:/j/hmbci.2018.34.issue-3/hmbci-2018-0009/ hmbci-2018-0009.xml. PMID: 29498934 DOI: 10.1515/ hmbci-2018-0009
Banu SK, Govindarajulu P, Aruldhas MM. Developmental profiles of TSH, sex steroids, and their receptors in the thyroid and their relevance to thyroid growth in immature rats. Steroids. 2002;67:137-44. PMID: 11755178 DOI: $10.1016 /$ S0039-128X(01)00144-1

Belviranli M, Baltaci AK. The relation between reduced serum melatonin levels and zinc in rats with induced hypothyroidism. Cell Biochem Funct. 2008;26:19-23. PMID: 17094164 DOI: 10.1002/cbf.1384

Biondi B, Cooper DS. The clinical significance of subclinical thyroid dysfunction. Endocr Rev. 2008;29:1:76-131. PMID: 17991805 DOI: 10.1210/er.2006-0043

Bondarenko LA, Sotnik NN, Chagovets EM, Sergienko LY, Cherevko AN. Intensity of in vitro incorporation of $3 \mathrm{H}$-melatonin in the thyroid gland of rabbits with pineal gland hypofunction. Bull Exp Bio Med. 2011;150:753-5. PMID: 22235435 DOI:https://doi.org/10.1007/s10517-011-1241-z

Brotfain E, Koyfman L, Frenkel A, Smolikov A, Zlotnik A, Klein $M$. Iodine-induced hyperthyroidism-an old clinical entity that is still relevant to daily ICU practice: a case report. Case Rep Endocrinol. 2013;2013:792745. PMID: 23653865 DOI: $10.1155 / 2013 / 792745$

Brzezinski A, Seibel MM, Lynch HJ, Deng MW, Wurtman RJ. Melatonin in human preovulatory follicular fluid. J Clin Endocrinol Metab. 1987;64:865-7. PMID: 3818907 DOI: 10.1210/jcem-64-4-865

Cabrera J, Negrín G, Estévez F, Loro J, Reiter RJ, Quintana J. Melatonin decreases cell proliferation and induces melanogenesis in human melanoma SK-MEL-1 cells. J Pineal Res. 2010;49:45-54. PMID: 20459460 DOI: 10.1111/j.1600-079X.2010.00765.X

Calvo R, Obregón MJ, Escobar del Rey F, Morreale de Escobar $\mathrm{G}$. The rat placenta and the transfer of thyroid hormones from the mother to the fetus. Effects of maternal thyroid status. Endocrinology. 1992;131:357-65. PMID: 1612015 DOI: $10.1210 /$ endo.131.1.1612015

Chaker L, Bianco AC, Jonklaas J, Peeters RP. Hypothyroidism. Lancet. 2017;390:1550-62. PMID: 28336049 DOI: $10.1016 / \mathrm{S} 0140-6736(17) 30703-1$

Chan S, Kilby MD. Thyroid hormone and central nervous system development. J Endocrinol. 2000;165:1-8. PMID: 10750030 DOI: $10.1677 /$ joe.0.1650001

Chastain CB, Ganjam VK, eds. Clinical Endocrinology of Companion Animals. 2nd ed. Philadelphia: WB Saunders; 1986.

Chen YC, Sheen JM, Tiao MM, Tain YL, Huang LT. Roles of melatonin in fetal programming in compromised pregnancies. Int J Mol Sci. 2013;14:5380-401. PMID: 23466884 DOI: $10.3390 /$ ijms 14035380

Choksi NY, Jahnke GD, St Hilaire C, Shelby M. Role of thyroid hormones in human and laboratory animal reproductive health. Birth Defects Res B Dev Reprod Toxicol. 2003;68:479-91. PMID: 14745982 DOI: 10.1002/ bdrb. 10045 
Claustrat B, Brun J, Chazot G. The basic physiology and pathophysiology of melatonin. Sleep Med Rev. 2005;9:1124. PMID: 15649735 DOI: 10.1016/j.smrv.2004.08.001

Díez JJ, Iglesias P. Spontaneous subclinical hypothyroidism in patients older than 55 years: an analysis of natural course and risk factors for the development of overt thyroid failure. J Clin Endocrinol Metab. 2004;89:4890-7. PMID: 15472181 DOI: 10.1210/jc.2003-032061

Dong J, Albertini DF, Nishimori K, Kumar TR, Lu N, Matsuk MM. Growth differentiation factor- 9 is required during early ovarian folliculogenesis. Nature. 1996;383:531-5. PMID: 8849725 DOI: $10.1038 / 383531 a 0$

Escames G, Ozturk G, Baño-Otálora B, Pozo MJ, Madrid JA, Reiter RJ, Serrano E, Concepcíon M, Acuña-Castroviejo D. Exercise and melatonin in humans: reciprocal benefits. J Pineal Res. 2012;52:1-11. PMID: 21848991 DOI: 10.1111/j.1600-079X.2011.00924.x

Evans KW, Farwell AP, Braverman LE. Nuclear thyroid hormone receptor in the rat uterus. Endocrinology. 1983;113:1459-63. PMID: 6311523 DOI: 10.1210/endo113-4-1459

Fadlalla MB, Wei Q, Fedall JS, Mehfooz A, Mao D, Shi F. Effects of hyper- and hypothyroidism on the development and proliferation of testicular cells in prepubertal rats. Anim Sci J. 2017;88:1943-54. PMID: 28782242 DOI: 10.1111/ asj. 12883

Fatourechi V. Subclinical hypothyroidism: an update for primary care physicians. Mayo Clin Proc. 2009;84:65-71. PMID: 19121255 DOI: 10.4065/84.1.65

Feldt-Rasmussen U, Klose M. Central hypothryroidism and its role for cardiovascular risk factors in hypopituitary patients. Endocrine. 2016;54:15-23. PMID: 27481361 DOI: $10.1007 / \mathrm{s} 12020-016-1047-x$

Ferreira CS, Maganhin CC, Simoes RS, Girão MJBC, Baracat EC, Soares Jr JM. Melatonin: cell death modulator. Rev Assoc Med Bras (1992) . 2010;56:715-8. PMID: 21271142 DOI: $10.1590 / S 0104-42302010000600024$

Galton VA, Martinez E, Hernandez A, St Germain EA, Bates JM, St Germain DL. The type 2 iodothyronine deiodinase is expressed in the rat uterus and induced during pregnancy. Endocrinology. 2001;142:2123-8. PMID: 11316780 DOI: 10.1210/endo.142.5.8169

Gholami M, Hemadi M, Saki G, Zendedel A, Khodadadi A, Mohammadi-Asi J. Does prepurbetal testicular tissue vitrification influence spermatogonial stem cells (SSCs) viability? J Assist Reprod Gen. 2013;30:1271-7. PMID: 23877786 DOI: 10.1007/s10815-013-0050-x

Gholami M, Saki G, Hemadi M, Khodadadi A, MohammadiAsi J. Melatonin improves spermatogonial stem cells transplantation efficiency in azoospermic mice. Iran J Basic Med Sci. 2014;17:93-9. PMID: 24711891

Hapon MB, Simoncini M, Via G, Jahn GA. Effect of hypothyroidism on hormone profiles in virgin, pregnant and lactating rats, and on lactation. Reproduction. 2003;126:371-82. PMID: 12968945 DOI: 10.1530/ rep. 0.1260371
Hapon MB, Motta AB, Ezquer M, Bonafede M, Jahn GA. Hypothyroidism prolongs corpus luteum function in the pregnant rat. Reproduction. 2007;133:197-205. PMID: 17244746 DOI: $10.1530 /$ REP-06-0035

Hapon MB, Gamarra-Luques C, Jahn GA. Short term hypothyroidism affects ovarian function in the cycling rat. Reprod Biol Endocrinol. 2010;8:14. PMID: 20149258 DOI: 10.1186/1477-7827-8-14

Hayashi M, McGee EA, Min G, Klein C, Rose UM, van Duin $M$, Hsueh AJ. Recombinant growth differentiation factor- 9 (GDF-9) enhances growth and differentiation of cultured early ovarian follicles. Endocrinology. 1999;140:1236-44. PMID: 10067849 DOI: 10.1210 /endo.140.3.6548

Huber G, Staub JJ, Meier C, Mitrache C, Guglielmetti M, Huber $P$, Braverman LE. Prospective study of the spontaneous course of subclinical hypothyroidism: prognostic value of thyrotropin, thyroid reserve, and thyroid antibodies. J Clin Endocrinol Metab. 2002;87:3221-6. PMID: 12107228 DOI: 10.1210/jcem.87.7.8678

Idris I, Srinivasan R, Simm A, Page RC. Maternal hypothyroidism in early and late gestation: effects on neonatal and obstetric outcome. Clin Endocrinol (Oxf). 2005;63:560-5. PMID: 16268809 DOI: 10.1111/j.1365-2265.2005.02382.x

James SR, Franklyn JA, Kilby MD. Placental transport of thyroid hormone. Best Pract Res Clin Endocrinol Metab. 2007;21:253-64. PMID: 17574007 DOI: 10.1016/j. beem.2007.03.001

Junqueira LCU, Carneiro J. Histologia básica. $13^{a}$ ed. Rio de Janeiro: Guanabara Koogan; 2013. (In Portuguese).

Kaklamanos I, Zaroska M, Flessas I, Zoulamoglou M, Katsoulas T, Birbas K, Troupis T, Mariolis-Sapsakos T. Surgical anatomy of double pyramidal lobe on total thyroidectomy: a rare case report. Int J Surg Case Rep. 2017; 2017:rjx035. PMID: 28458845 DOI: $10.1093 /$ jscr/rjx035

Karabinas CD, Tolis GJ. Thyroid disorders and pregnancy. J Obstet Gynaecol. 1998;18:509-15. PMID: 15512165 DOI: $10.1080 / 01443619866219$

Kirkland JL, Gardner RM, Mukku V, Akhtar M, Stancel GM. Hormonal control of uterine growth: the effect of hypothyroidism on estrogen-stimulated cell division. Endocrinology. 1981;108:2346-51. PMID: 7227309 DOI: 10.1210/endo-108-6-2346

Kuş I, Sarsilmaz M, Ogetürk M, Yilmaz B, Keleştimur H, Oner $\mathrm{H}$. Ultrastructural interrelationship between the pineal gland and the testis in the male rat. Arch Androl. 2000;45:11924. PMID: 11028930 DOI: $10.1080 / 014850100418819$

Laskar P, Acharjee S, Singh SS. Effect of Exogenous Melatonin on Thyroxine (T4), Thyrotropin (TSH) Hormone Levels and Expression patterns of Melatonin Receptor (MT1 and MT2) Proteins on Thyroid gland during Different age groups of Male and Female Swiss albino Mice. Adv Biores. 2015;6:7-14. DOI: 10.15515/abr.0976-4585.6.1.714

Lee $H$, Kim S, Kim D. Effects of exercise with or without light exposure on sleep quality and hormone reponses. J Exerc Nutrition Biochem. 2014;18:293-9. PMID: 25566466 DOI: $10.5717 /$ jenb.2014.18.3.293 
León J, Acuña-Castroviejo D, Escames G, Tan DX, Reiter RJ. Melatonin mitigates mitochondrial malfunction. J Pineal Res. 2005;38:1-9. PMID: 15617531 DOI: $10.1111 / \mathrm{j} .1600-$ 079X.2004.00181.x

Leonard AJ, Evans IM, Pickard MR, Bandopadhyay R, Sinha AK, Ekins RP. Thyroid hormone receptor expression in rat placenta. Placenta. 2001;22:353-9. PMID: 11286572 DOI: 10.1053 /plac. 2000.0617

Li C, Zhou X. Melatonin and male reproduction. Clin Chim Acta. 2015;446:175-80. PMID: 25916694 DOI: 10.1016/j. cca.2015.04.029

Maciel LM, Magalhães PK. Thyroid and Pregnancy. Arq Bras Endocrinol Metabol. 2008;52:1084-95. PMID: 19082296 DOI: $10.1590 / S 0004-27302008000700004$

Maganhin CC, Carbonel AAF, Hatty JH, Fuchs LF, OliveiraJúnior IS, Simões Mde J, Simões RS, Baracat EC, Soares JM Jr. Melatonin effects on the female genital system: a brief review. Rev Assoc Med Bras (1992). 2008;54:267-71. PMID: 18604407 DOI: 10.1590/S010442302008000300022

Maganhin CC, Simões RS, Fuchs LF, Oliveira-Filho RM, Simões MJ, Evêncio-Neto J, Bacarat EC, Soares-Junior JM. Rat pinealectomy: a modified direct visual approach. Acta Cir Bras. 2009;24:321-4. PMID: 19705033 DOI: 10.1590/ S0102-86502009000400013

Maganhin CC, Fuchs LF, Simões RS, Oliveira-Filho RM, Simões MJ, Baracat EC, Soares-Junior JM. Effects of melatonin on ovarian follicles. Eur J Obstet Gynecol Reprod Biol. 2013;166:178-84. PMID: 23102587 DOI: 10.1016/j. ejogrb.2012.10.006

Maldonado MD, Manfredi M, Ribas-Serna J, Garcia-Moreno $\mathrm{H}$, Calvo JR. Melatonin administered immediately before an intense exercise reverses oxidative stress, improves immunological defenses and lipid metabolism in football players. Physiol Behav. 2012;105:1099-103. PMID: 22212240 DOI: $10.1016 / j$.physbeh.2011.12.015

Maruo T, Katayama K, Barnea ER, Mochizuki M. A role for thyroid hormone in the induction of ovulation and corpus luteum function. Horm Res. 1992;37:12-8. PMID: 1427622 DOI: $10.1159 / 000182338$

McGrath SA, Esquela AF, Lee SJ. Oocyte-specific expression of growth/differentiation factor-9. Mol Endocrinol. 1995;9:131-6. PMID: 7760846 DOI: 10.1210/ mend.9.1.7760846

Mendis-Handagama SC, Kerr JB, De Kretser DM. Experimental cryptorchidism in the adult mouse. III. Qualitative and quantitative electron microscopic morphology of Leydig cells. J Androl. 1991;12:33543. PMID: 1684973 DOI: 10.1002/j.1939-4640.1991. tb01613.x

Meng L, Rijntjes E, Swarts HJM, Keijer J, Teers KJ. Prolonged hypothyroidism severely reduces ovarian follicular reserve in adult rats. J Ovarian Res. 2017;10:19. PMID: 28302175 DOI: $10.1186 / s 13048-017-0314-7$
Menzilcioglu MS, Duymus M, Avcu S. Sonographic Elastography of the Thyroid Gland. Pol J Radiol. 2016;81:152-6. PMID: 27103947 DOI: $10.12659 /$ PJR.896178

Mitchell B, Sharma R, eds. Embryology - An Illustrated Colour Text. 2nd ed. London: Churchill Livingstone; 2009.

Morreale de Escobar G, Obregon MJ, Escobar del Rey F. Role of thyroid hormone during early brain development. Eur J Endocrinol. 2004;151:U25-37. PMID: 15554884 DOI: $10.1530 /$ eje.0.151u025

Mukherjee A, Haldar C. Photoperiodic regulation of melatonin membrane receptor (MT1R) expression and steroidogenesis in testis of adult golden hamster, Mesocricetus auratus. J Photochem Photobiol B. 2014;140:374-80. PMID: 26151342 DOI: 10.1016/j. jphotobiol.2014.08.022

Mutvei A, Nelson BD. The response of individual polypeptides of the mammalian respiratory chain to thyroid hormone. Arch Biochem Biophys. 1989;268:215-20. PMID: 2536261 DOI: $10.1016 / 0003-9861(89) 90582-1$

Nelissen EC, van Montfoort AP, Dumoulin JC, Evers JL. Epigenetics and the placenta. Hum Reprod Update. 2011;17:397-417. PMID: 20959349 DOI: 10.1093/ humupd/dmq052

Niu B, Li B, Wu C, Wu J, Yan Y, Shang R, Bai C, Li G, Hua J. Melatonin promotes goat spermatogonia stem cells (SSCs) proliferation by stimulating glial cell line-derived neurotrophic factor (GDNF) production in Sertoli cells. Oncotarget. 2016;7:77532-42. PMID: 27769051 DOI: 10.18632/oncotarget. 12720

Oppenheimer JH, Schwartz HL, Mariash CN, Kinlaw WB, Wong $\mathrm{NC}$, Freake HC. Advances in our understanding of thyroid hormone action at the cellular level. Endocr Rev. 1987;8:288308. PMID: 3308445 DOI: 10.1210/edrv-8-3-288

Orisaka M, Orisaka S, Jiang JY, Craig J, Wang Y, Kotsuji F, Tsang BK. Growth differentiation factor-9 is antiapoptotic during follicular development from preantral to early antral stage. Mol Endocrinol. 2006;20:2456-68. PMID: 16740654 DOI: $10.1210 /$ me.2005-0357

Parker GA, Picut CA, eds. Atlas of Histology of the Juvenile Rat. 1st ed. Cambridge: Academic Press; 2016.

Picut CA, Remick AK, Asakawa MG, Simons ML, Parker GA. Histologic features of prepubertal and pubertal reproductive development in female Sprague-Dawley rats. Toxicol Pathol. 2014;42:403-13. PMID: 23599412 DOI: $10.1177 / 0192623313484832$

Picut CA, Dixon D, Simons ML, Stump DG, Parker GA, Remick AK. Postnatal ovary development in the rat: morphologic study and correlation of morphology to neuroendocrine parameters. Toxicol Pathol. 2015a;43:343-53. PMID: 25107574 DOI: $10.1177 / 0192623314544380$

Picut CA, Remick AK, de Rijk EP, Simons ML, Stump DG, Parker GA. Postnatal development of the testis in the rat: morphologic study and correlation of morphology to neuroendocrine parameters. Toxicol Pathol. 2015b;43:32642. PMID: 25217330 DOI: 10.1177/0192623314547279 
Reiter RJ. Functional pleiotropy of the neurohormone melatonin: antioxidant protection and neuroendocrine regulation. Front Neuroendocrinol. 1995;16:383-415. PMID: 8557171 DOI: 10.1006/frne.1995.1014

Reiter RJ. Mechanisms of cancer inhibition by melatonin. J Pineal Res. 2004;37:213-4. PMID: 15357667 DOI: 10.1111/j.1600-079X.2004.00165.X

Rocha RMP, Matos MHT, Lima LF, Saraiva MVA, Alves AMCV, Rodrigues APR, Figueiredo JR. Melatonin and animal reproduction: implications on ovarian physiology. Acta Vet Bras. 2011;5:147-57.

Rom-Bugoslavskaia ES, Bondarenko LA. Effect of deficiency and excess of thyroid hormones in the body on indolamine metabolism in the rat epiphysis cerebri. Probl Endokrinol (Mosk). 1984;30:82-5. PMID:6209708

Sanyal D, Raychaudhuri M. Hypothyroidism and obesity: an intriguing link. Indian J Endocrinol Metab. 2016;20:554-7. PMID: 27366725 DOI: 10.4103/2230-8210.183454

Sharma S, Singh H, Ahmaad N, Mishra P, Tiwari A. The role of melatonin in diabetes: therapeutic implications. Arch Endocrinol Metab. 2015;59:391-9. PMID: 26331226 DOI: $10.1590 / 2359-3997000000098$

Shizuma T. Concomitant thyroid disorders and inflammatory bowel disease: a literature review. Biomed Res Int. 2016;2016:5187061. PMID: 27042663 DOI: $10.1155 / 2016 / 5187061$

Silva JF, Vidigal PN, Galvão DD, Boeloni JN, Nunes PP, Ocarino NM, Nascimento EF, Serakides R. Fetal growth restriction in hypothyroidism is associated with changes in proliferative activity, apoptosis and vascularisation of the placenta. Reprod Fertil Dev. 2012;24:923-31. PMID: 22935153 DOI: $10.1071 /$ RD11219

Silva JF, Ocarino NM, Serakides R. Maternal thyroid dysfunction affects placental profile on inflammatory mediators and the intrauterine trophoblast migration kinetics. Reproduction. 2014;147:803-16. PMID: 24534949 DOI: $10.1530 /$ REP-13-0374

Skipor J, Misztal T, Kaczmarek MM. Independent changes of thyroid hormones in blood plasma and cerebrospinal fluid after melatonin treatment in ewes. Theriogenology. 2010;74:236-45. PMID: 20452012 DOI: 10.1016/j. theriogenology.2010.02.007

Smallridge RC, Ladenson PW. Hypothyroidism in pregnancy: consequences to neonatal health. J Clin Endocrinol Metab. 2001;86:6:2349-53. PMID: 11397821 DOI: 10.1210/ jcem.86.6.7577

Soares Jr JM, Simões RS, Simões MJ, Baracat EC. Aspectos moleculares dos receptores de melatonina e sua ação na reprodução. Femina. 2003;31:495-500.

Soukup T, Zacharová G, Smerdu V, Jirmanová I. Body, heart, thyroid gland and skeletal muscle weight changes in rats with altered thyroid status. Physiol Res. 2001;50:61926. PMID: 11829324
Sousa Coelho IDD, Lapa Neto CJC, Souza TGDS, Silva MAD, Chagas CA, Santos KRPD, Wanderley Teixeira V, Teixeira ÁAC. Protective effect of exogenous melatonin in rats and their offspring on the genotoxic response induced by the chronic consumption of alcohol during pregnancy. Mutat Res Genet Toxicol Environ Mutagen. 2018;832-833:52-60. PMID: 30057021 DOI: 10.1016/j.mrgentox.2018.06.018

Sumaya IC, Masana MI, Dubocovich ML. The antidepressantlike effect of the melatonin receptor ligand luzindole in mice during forced swimming requires expression of MT2 but not MT1 melatonin receptors. J Pineal Res. 2005;39:170-7. PMID: 16098095 DOI: $10.1111 / \mathrm{j} .1600-$ 079X.2005.00233.x

Surks MI, Ortiz E, Daniels GH, Sawin CT, Col NF, Cobin $\mathrm{RH}$, Franlyn JA, Hershman JM, Burman KD, Denke MA, Gorman C, Cooper RS, Weissman NJ. Subclinical thyroid disease: scientific review and guidelines for diagnosis and management. JAMA. 2004;292:228-38. PMID: 14722150 DOI: $10.1001 /$ jama.291.2.228

Tamura H, Nakamura Y, Korkmaz A, Manchester LC, Tan DX, Sugino N, Reiter RJ. Melatonin and the ovary: physiological and pathophysiological implications. Fertil Steril. 2009;92:328-43. PMID: 18804205 DOI: 10.1016/j. fertnstert.2008.05.016

Tamura H, Takasaki A, Taketani T, Tanabe M, Lee L, Tamura I, Maekawa R, Aasada H, Yamagata $Y$, Sugino N. Melatonin and female reproduction. J Obstet Gynecol Res. 2014;40:1-11. PMID: 24118696 DOI: 10.1111/ jog. 12177

Tuthill CR, Freeman DA, Butler MP, Chinn T, Park JH, Zucker I. Perinatal influences of melatonin on testicular development and photoperiodic memory in Siberian hamsters. J Neuroendocrinol. 2005;17:483-8. PMID: 16011484 DOI: $10.1111 /$ j.1365-2826.2005.01329.x

Vanderpump MP. The epidemiology of thyroid disease. $\mathrm{Br}$ Med Bull. 2011;99:39-51. PMID: 21893493 DOI: 10.1093/ bmb/ldr030

Vasudevan N, Ogawa S, Pfaff D. Estrogen and thyroid hormone receptor interactions: physiological flexibility by molecular specificity. Physiol Rev. 2002;82:923-44. PMID: 12270948 DOI: $10.1152 /$ physrev.00014.2002

Versloot PM, Schroder-van der Elst JP, van der Heide D, Boogerd L. Effects of marginal iodine deficiency during pregnancy: iodine uptake by the maternal and fetal thyroid. Am J Physiol. 1997;273:E1121-6. PMID: 9435527 DOI: 10.1152/ajpendo.1997.273.6.E1121

Wagner MS, Wajner SM, Maia AL. The role of thyroid hormone in testicular development and function. J Endocrinol. 2008;199:351-65. PMID: 18728126 DOI: 10.1677/JOE-08-0218

Waseem M, Sahu U, Salman M, Choudhury A, Kar $\mathrm{S}$, Tabassum H, Parvez S. Melatonin pre-treatment mitigates SHSY-5Y cells against oxaliplatin induced mitochondrial stress and apoptotic cell death. PLoS One. 2017;12:e0180953. PMID: 28732061 DOI: 10.1371/ journal.pone.0180953 
Welsh KJ, Soldin SJ. Diagnosis of endocrine disease: how reliable are free thyroid and total T3 hormone assays? Eur J Endocrinol. 2016;175:255-63. PMID: 27737898 DOI: 10.1530/EJE-16-0193

Wilhelm D, Palmer S, Koopman P. Sex determination and gonadal development in mammals. Physiol Rev. 2007;87:1-28. PMID: 17237341 DOI: 10.1152/ physrev.00009.2006

Yim $\mathrm{CH}$. Update on the Management of Thyroid Disease during Pregnancy. Endocrinol Metab (Seoul). 2016;31:386-91. PMID: 27546871 DOI: 10.3803/ EnM.2016.31.3.386
Zayed AE, Abd-Elnaeim MM, Abd-Elghaffar SK, Hild A, Brehm R, Steger K. Prenatal development of murine gonads with special reference to germ cell differentiation: a morphological and immunohistochemical study. Andrologia. 2007;39:93-100. PMID: 17683469 DOI: 10.1111/j.1439-0272.2007.00771.x

Zirkin BR, Ewing LL, Kromann N, Cochran RC. Testosterone secretion by rat, rabbit, guinea pig, dog, and hamster testes perfused in vitro: correlation with Leydig cell ultrastructure. Endocrinology. 1980;107:1867-74. PMID: 7428694 DOI: $10.1210 /$ endo-107-6-1867 